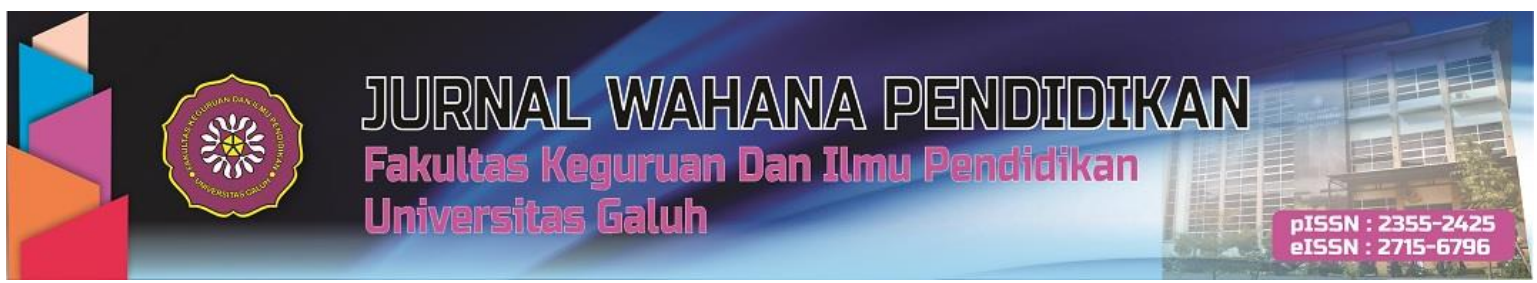

https://jurnal.unigal.ac.id/index.php/jwp

\title{
MENINGKATKAN KOMPETENSI GURU DALAM PENYUSUNAN RENCANA PELAKSANAAN PEMBELAJARAN MELALUI SUPERVISI KELOMPOK
}

\author{
Sriyanto \\ SMK Negeri 1 Salatiga, Jl. Nakula-Sadewa I/3 Sidomukti, Kota Salatiga Kode Pos 50772, Indonesia \\ E-mail : yanto.sri51@yahoo.co.id
}

\begin{abstract}
ABSTRAK
Tujuan penelitian ini untuk mendapatkan gambaran tentang peningkatakan kompetensi guru dalam pembuatan Rencana Pelaksanaan Pembelajaran (RPP) di SMK Negeri 1 Salatiga pada semester gasal tahun pelajaran 2020/ 2021. Metode pendekatan penelitian yang digunakan adalah Penelitian Tindakan Sekolah (PTS) yaitu penelitian yang dilakukan oleh Kepala Sekolah di sekolah tempat bertugas. Penelitian ini menggunakan 2 siklus. Dalam setiap siklus terdiri dari perencanaan, pelaksanaan, pengamatan, dan refleksi. Obyek sekaligus subyek penelitian adalah guru SMK Negeri 1 Salatiga Kota Salatiga tahun pelajaran 2020/2021 berjumlah 78. Teknik analisis data digunakan analisis perbandingan, artinya data awal sebelum mulai penelitian menjadi dasar, dibandingkan dengan hasil siklus I kemudian disempurnakan pada siklus II. Dari seluruh siklus yang telah dilakukan, dapat disimpulkan bahwa supervise kelompok dapat dijelaskan bahwa: 1) Nilai rata-rata pra-siklus adalah 62. 2) Nilai rata-rata RPP pada siklus I mencapai 93. Pada siklus ke II nilai ratarata RPP meningkat menjadi 97. Kompetensi guru dalam pembuatan Rencana Pelaksanaan Pembelajaran (RPP) dapat meningkat melalui kegiatan supervise kelompok di SMK Negeri 1 Salatiga Kota Salatiga Tahun Pelajaran 2020/2021.
\end{abstract}

Kata Kunci : supervisi kelompok, kompetensi guru, Rencana Pelaksanaan Pembelajaran (RPP)

\begin{abstract}
This study aims to determine the effect of group supervision on increasing teacher competence in the preparation of a Learning Implementation Plan (RPP) at SMK Negeri 1 Salatiga, Salatiga City, 2020/2021 Academic Year. The research approach method used was School Action Research (PTS), namely research conducted by the principal at the school where he served. This study used 2 cycles. Each cycle consists of planning, implementing, observing, and reflecting. The object and subject of the research were 78 teachers of SMK Negeri 1 Salatiga, City of Salatiga in the academic year 2020/2021. The data analysis technique used comparative analysis, meaning that the initial data before starting the study became the basis, compared to the results of cycle I then refined in cycle II. From all the cycles that have been carried out, it can be concluded that the group supervision can be explained that: 1) The pre-cycle average value is 62. 2) The average value of the RPP in cycle I reaches 93 . In the second cycle the average value of the RPP increased to 97 . It turns out that group supervision can improve teacher competence in preparing lesson plans at SMK Negeri 1 Salatiga, Salatiga City, 2020/2021 academic year.
\end{abstract}

Keywords: group supervision, teacher competence, lesson plan (RPP)

Cara sitasi:

Sriyanto. (2021). Meningkatkan Kompetensi Guru Dalam Penyusunan Rencana Pelaksanaan Pembelajaran Melalui Supervisi Kelompok. Jurnal Wahana Pendidikan, 8 (1), 103- 110.

Sejarah Artikel:

Dikirim Desember 2020, Direvisi Januari 2021, Diterima Januari 2021 


\section{PENDAHULUAN}

Tugas utama guru adalah menyusun perencanaan pembelajaran atau pemsupervisi, melaksanakan kegiatan belajar mengajar atau supervisi di kelas, melakukan penilaian proses dan hasil belajar atau pemsupervisi, mengadakan kegiatan supervisi dan latihan kepada peserta didik, dan melakukan tugas tambahan seperti wali kelas, pembimbing ekstrakuriler, wakil kepala sekolah, dan laboran. Pada kegiatan petencanaan pembelajaran atau supervisi terdapat 3 (tiga) kegiatan yang meliputi : pengkajian kurikulum dan silabus pembelajaran/pemsupervisi/program kebutuhan khusus pada satuan pendidikan, pengkajian program tahunan dan semester serta Rencana Pelaksanaan Pembelajaran/Pemsupervisi (RPP).

Berdasarkan Surat Edaran Menteri Pendidikan dan Kebudayaan Nomor 14 tahun 2019 dijelaskan bahwa penyusunan RPP dilakukan dengan prinsip efisien, efektif, dan berorientasi pada siswa. Dari 13 komponen RPP yang tertuang dalam Permendikbud Nomor 22 Tahun 2016, yang menjadi komponen inti adalah tujuan pembelajaran, langkah-langkah pembelajaran, dan penilaian pembelajaran (assesment) yang wajib dilaksanakan oleh guru, sedangkan sisanya hanya sebagai pelengkap.

Efisien berarti penulisan RPP dilakukan dengan tepat dan tidak menghabiskan banyak waktu dan tenaga. Efektif berarti penulisan RPP dilakukan untuk mencapai tujuan pembelajaran. Berorientasi pada murid berarti penulisan RPP dilakukan dengan mempertimbangkan kesiapan, ketertarikan, dan kebutuhan belajar murid di kelas.

RPP dapat dibuat dengan singkat misalnya hanya satu halaman, asalkan sesuai dengan prinsip efisien, efektif, dan berorientasi kepada murid. Tidak ada persyaratan jumlah halaman Selama ini guru-guru sering diarahkan untuk membuat RPP dengan rinci yang menghabiskan waktu yang seharusnya bisa lebih difokuskan untuk mempersiapkan (membuat media) dan mengevaluasi proses pembelajaran itu sendiri.

Oleh karena itu sekolah, KKG/MGMP, dan individu guru secara bebas dapat memilih, membuat, menggunakan, dan mengembangkan format RPP secara mandiri untuk sebesar-besarnya keberhasilan belajar siswa.

Di SMK Negeri 1 Salatiga 67 dari 78 guru (86\%) berhasil dilakukan wawancara. Bahwa dari 67 guru, 51 (76\%) menyatakan pernah membaca Surat Edaran Menteri Pendidikan dan Kebudayaan Nomor 14 tahun 2019. 8 orang (10\%) pernah mengikuti pelatihan pembuatan RRP satu halaman dan 59 lainnya $(76 \%)$ menyatakan belum pernah. Mengingat keberhasilan pembelajaraan sangat ditentukan oleh kualitas RPP yang disusun guru, maka perlu segera dilaksanakan supervisi kelompok khususnya dalam hal penyusunan RPP. Dari hasil wawancara juga diketahui bahwa 59 dari 67 guru bersedia menerima supervisi kelompok untuk membuat RPP sesuai dengan surat edaran tersebut.

Keunggulan supervisi kelompok adalah hubungan interpersonal antara guru dan kepala sekolah lebih dekat sehingga guru dapat lebih leluasa dalam mengungkapkan kesulitan dan hambatan dalam penyusunan RPP. Berdasarkan penjelasan tersebut, peneliti terdorong untuk memberikan supervisi agar supaya para guru di SMK Negeri 1 Salatiga dapat membuat RPP sesuai dengan ketentuan Surat Edaran Menteri Pendidikan dan Kebudayaan Nomor 14 tahun 2019. Di samping itu juga diharapkan ada standarisasi RPP baik konten maupun formatnya.

Dengan melalui supervisi kelompok diharapkan guru SMK Negeri 1 Salatiga mengalami peningkatan kompetensi dalam kemampuannya menyusun RPP. Lebih dari itu seluruh guru menyusun RPP sesuai dengan mata pelajaran dan kelas dimana ia mengajar.

\section{METODE PENELITIAN}

Untuk meningkatkan kemampuan guru dalam pembuatan RPP, kepala sekolah melakukan penelitian tindakan sekolah (School Action Research), yaitu kegiatan penelitian yang melibatkan guru dan kepala sekolah dalam rangka meningkatkan kompetensi atau kemampuan guru melalui kegiatan yang dilakukan oleh kepala sekolah dengan melalui langkah-langkah tertentu yang sesuai kaidah ilmiah. Berawal dari masalah yang dihadapi guru, kepala sekolah menyusun alternatif-alternatif untuk 
mendapatkan solusi. Dari sekian alternatif ditetapkan alternatif terpilih dan kemudian diimplentasikan. Hasilnya dinilai dan diperbaiki atau ditingkatkan pada siklus tahap selanjutnya sampai mendapatkan hasil sesuai dengan indikator yang ditetapkan.

Di SMK Negeri 1 Salatiga pada bulan Mei 2020 terdapat guru sejumlah 89, terdiri dari 78 orang Pegawai Negeri Sipil (PNS) dan 12 orang GTT. Dari 78 orang guru PNS terdapat 1 orang guru mata pelajaran yang pada 1 Juni 2020 memasuki pensiun dan dari 12 orang GTT ada 1 orang yang mengundurkan diri sehingga tidak dimasukkan dalam subyek/ obyek penelitian. Dari 89 orang guru, sesuai dengan tugasnya terdapat 86 guru mata pelajaran dan 6 orang guru bimbingan konseling (BK). Karena kekhususannya 6 orang guru BK tidak masuk dalam subyek/obyek penelitian. Dari 12 GTT terdapat 3 orang guru agama non-Agama Islam yang tidak berpangkalan di SMK Negeri 1 Salatiga juga tidak masuk di dalam subyek penelitian. Dengan demikian terdapat 78 guru yang menjadi subyek/ obyek penelitian.

Metode deskriptif dipilih dalam penelitian ini. Menurut Nawawi, metode deskriptif dapat diartikan sebagai prosedur pemecahan masalah yang diselidiki dengan menggambarkan atau melukiskan keadaan subyek atau obyek penelitian (sesorang, lembaga, masyarakat dan lain-lain) pada saat sekarang berdasarkan fakta-fakta yang tampak atau sebagaimana adanya (1985:63). Data yang peneliti kumpulkan melalui angket, wawancara, diskusi, dan observasi/pengamatan yang berupa persentase atau angka-angka akan dijelaskan dengan menggunakan metode penelitian ini.

Melalui penelitian ini diharapkan dapat mengurai kesulitan-kesulitan yang dialami oleh guru dalam menyusun RPP. Langkah berikutnya, peneliti memberikan alternatif atau usaha guna meningkatkan kemampuan guru dalam membuat rencana pelaksanaan pembelajaran. Alternatif yang terpililh kemudian dilaksanakan untuk mendapatkan solusi terbaik. RPP pra-siklus menjadi pangkal tolak untuk dibandingkan dengan RPP hasil pelaksanaan siklus untuk menentukan keberhasilan penelitian.

Penelitian Tindakan Sekolah ini terdiri dari 2 (dua) siklus. Setiap siklus terdiri dari 2 (dua) kali pertemuan dan siklus memiliki langkah-langkah : (1) Perencanaan, Tindakan apa yang akan dilakukan oleh peneliti untuk membantu guru dalam rangka meningkatkan kompetensinya di dalam menyusun atau membuat RPP; (2) Pelaksanaan. Pada tahap ini, peneliti menetapkan apa yang akan dilakukan sebagai upaya meningkatkan kompetensi guru dalam menyusun RPP yang sesuai dengan surat edaran menteri. Pada tahap pelaksanaan ini, peneliti memberikan supervisi kelompok kepada guru di SMK Negeri 1 Salatiga secara daring; (3) Observasi. Kegiatan observasi adalah kegiatan pengamatan terhadap RPP yang telah dibuat untuk memotret seberapa jauh kemampuan guru dalam menyusun RPP dengan lengkap, hasil atau dampak dari tindakan yang telah dilaksanakan oleh guru dalam mencapai sasaran. Selain itu juga peneliti mencatat hal-hal yang terjadi dalam pertemuan. Rekaman dari pertemuan akan digunakan untuk melakukan analisis perbaikan pada siklus berikutnya; (4) Refleksi. Yaitu suatu kegiatan untuk melakukan perenungan tentang apa saja yang sudah dilakukan atau belum dilakukan, apa saja yang sudah dihasilkan atau belum dihasilkan, apa saja yang sudah dicapai atau belum dicapai. Hasil refleksi itu digunakan untuk menetapkan langkah lebih lanjut dalam upaya mencapai tujuan PTS. Pada tahap ini peneliti mengkaji, melihat, dan mempertimbangkan hasil atau dampak dari tindakan yang telah dilakukan. Hasil dari refleksi digunakan peneliti bersama guru untuk melaksanakan revisi atau perbaikan terhadap RPP yang telah disusun pada siklus berikutnya. Hasil akhir yang diharapkan dari penelitian ini adalah minimal $75 \%$ dari jumlah guru mendapatkan nilai minimal 75 .

\section{HASIL DAN PEMBAHASAN}

Hasil wawancara sebelum penelitian dari 78 guru, 76 guru (97\%) mengakui bahwa RPP yang baik akan mempengaruhi mutu pembelajaran. Oleh karena itu mereka pada semester gasal tahun pelajaran 2020/ 2021 bersedia menyusun RPP sendiri (bukan copy paste). Kemudian 88\% guru juga bersedia menerima supervisi untuk membuat RPP sesuai dengan Surat Edaran Menteri Pendidikan dan Kebudayaan Nomor 14 tahun 2019. 
Dari 78 guru yang diberi angket, ada 72 mengisi dan mengembalikan kepada peneliti. Dari angket itu diketahui rata-rata skor klasikal adalah $79,70 \%$ dengan nilai rata-rata $78,46 \%$. Ini menunjukkan bahwa komitmen guru dalam menyusun RPP dan pentingnya RPP terkait dengan mutu pembelajaran cukup tinggi.

Sebelum melakukan supervisi pembuatan RPP, peneliti menyampaikan sosialisasi Surat Edaran Menteri Pendidikan dan Kebudayaan Nomor 14 tahun 2019 tentang penyederhanaan Rencana Pelaksanaan Pembelajaran (RPP). Kemudian guru diminta untuk membuat RPP sesuai dengan surat edaran itu.

Dari 78 guru diketahui ada $7(9 \%)$ orang guru yang tidak membuat RPP. Dari nilai RPP prasiklus diketahui bahwa mereka yang dinyatakan tuntas ada 23 orang $(29 \%)$ dan belum yang mencapai batas ketuntasan 48 orang (62\%). Nilai rata-rata RPP adalah 62.

Melalui wawancara dengan beberapa guru diketahui bahwa mereka belum sungguh-sungguh dalam penyusunan RPP. Di samping itu mereka juga tidak menyangka jika RPPnya dikoreksi dengan teliti oleh kepala sekolah.

Melihat capaikan ketuntasan yang masih sangat rendah, mendorong peneliti untuk semakin tertantang dalam memberikan supervisi. Untuk itu peneliti melaksanakan langkah siklus I.

\section{Siklus I (Pertama)}

Siklus I dilaksanakan pada 12 Mei 2020 dan 19 Mei 2020. Siklus I terdiri dari empat tahap yakni: (1) perencanaan, (2) pelaksanaan, (3) observasi, dan (4) refleksi.

\section{Perencanaan (Planning)}

Aktifitas pada kegiatan perencanaan adalah menyiapkan dokumen yang diperlukan dalam pelaksanaan penelitian, membuat rancangan waktu penelitian, dan membuat strategi pelaksanaan penelitian. Mengingat penelitian pada masa pandemi, maka pelaksanaannya dilakukan secara daring. Adapun dokumennya antara lain : instrument panduan wawancara, angket, template form RPP, rubrik penilaian RPP, form penilaian, form rekap nilai dan bahan paparan (ppt).

2. Pelaksanaan (Acting)

Pada siklus I pertemuan pertama guru dijelaskan tentang komponen utama RPP satu halaman (Tujuan Pembelajaran, Langkah-langkah Pembelajaran dan Penilaian Pembelajaran). Disamping itu RPP juga harus dilengkapi dengan identitas (nama satuan pendidikan, nama mata pelajaran, kelas/ semester, tahun pelajaran, materi pokok dan pertemuan ke- serta alokasi waktu). Pada pertemuan kedua, guru praktik membuat RPP. Sebelum guru praktik membuat RPP, peneliti memberikan contoh nyata RPP dan formatnya.

3. Observasi

Dari hasil observasi dapat dikemukakan sebagai berikut.

a. Satu orang guru tidak menyusun RPP.

b. Dari 77 guru yang menyusun RPP, 75 orang (97\%) mendapatkan nilai tuntas dan 2 guru tidak tuntas $(3 \%)$.

c. Nilai rata-rata RPP adalah 93.

4. Refleksi

Berdasarkan hasil observasi, peneliti melakukan refleksi untuk:

a. Membuat agar 1 (satu) orang guru yang belum menyusun RPP baik pada pra siklus maupun siklus I pada siklus II nanti mau menyusun. Direncanakan oleh peneliti kepada yang bersangkutan akan dilakukan pendekatan secara persuasif untuk mendapat informasi kendala/ hambatan/ alasan mengapa pada pra siklus maupun siklus I pada siklus II nanti mau menyusun RPP. Selanjutkan berdasarkan informasi itu peneliti akan memotivasi agar pada siklus II yang bersangkutan mau menyusun RPP. 
b. Menuntaskan 2 (dua) orang guru Bahasa Inggris yang nilainya masih di bawah 75 (56 dan 72). Direncanakan dengan melakukan wawancara kepada keduanya didapatkan informasi kendala/ hambatan/ alasan mengapa tidak tuntas. Dan setelah itu ditentukan solusinya.

c. Meningkatkan capaian nilai RPP. Meskipun nilai rata-rata yang dicapai sudah melampaui batas minimal ketuntasan (75), tetapi pada siklus II akan ditingkatkan dengan mengulas ulang kelemahan-kelemahan yang terdapat pada RPP siklus I.

\section{Siklus II (Kedua)}

Siklus II dilaksanakan pada 2 Juni 2020 dan 15 Juni 2020. Pada siklus II juga terdiri dari empat tahap yakni: (1) perencanaan, (2) pelaksanaan, (3) observasi, dan (4) refleksi.

Pada pertemuan pertama, peneliti menyampaikan hasil capaian RPP pada siklus I. Dua orang guru yang belum tuntas pada siklus I diajak wawancara secara khusus dan ditunjukkan kelemahan-kelemahannya. Keduanya menyadarinya dan akan memperbaiki pada pertemuan kedua. Pada sesi tanya jawab muncul usulan agar peneliti membuatkan format baku untuk RPP (templete) sehingga diharapkan format RPP terstandarisasikan.

1 (satu) orang guru yang belum membuat RPP dilakukan pendekatan persuasif dan wawancara tentang penyebab mengapa tidak membuat RPP. Akhirnya diketahui bahwa yang bersangkutan siap membuat RPP sesuai ketentuan.

Seperti pada siklus I, pada siklus II pertemuan kedua guru juga praktik membuat RPP dengan format yang sudah dibakukan. Hasil pembuatan RPP kemudian dilakukan observasi/ penilaian.

Dari hasil observasi siklus II diperoleh informasi sebagai berikut :

a. Seluruh guru sudah menyusun RPP $(100 \%)$.

b. Seluruh guru sudah mencapai nilai tuntas.

c. Nilai rata-rata RPP adalah 97.

Dari uraian di atas dapat disimpulkan bahwa pada siklus I kesadaran tentang pentingnya membuat RPP sendiri makin tinggi. Di sisi lain juga didapati hasil yang dicapai naik cukup signifikan bahkan indikator keberhasilan yang ditetapkan peneliti sudah tercapai. Indikasi keberhasilan itu dapat dipaparkan berikut ini.

1. Jumlah yang membuat RPP ada 77 orang. Berarti hanya tinggal 1 orang yang belum membuat dan kami motivasi agar pada siklus berikutnya membuat RPP. Artinya dari 78 orang hanya 1 (satu) orang yang belum membuat. Dengan hasil penilaian yang ditayangkan secara terbuka, peneliti melakukan akuntabilitas publik dengan harapan setiap guru mendapat informasi berapa capaian nilai yang diperoleh. Jika seorang guru mendapatkan nilai yang tinggi, agar terus dijaga dan dilaksanakan sekaligus sebagai modal untuk memberikan mentoring bagi guru yang belum mencapai batas ketuntasan. Bagi guru yang belum mencapai ketuntasan termasuk 1 (satu) orang guru yang belum membuat RPP, dengan bimbingan dan motivasi kepala sekolah diharapkan pada siklus berikutnya sudah membuat RPP dan dapat mencapai ketuntasan.

2. 75 orang guru $(97 \%)$ RPPnya tuntas (mencapai nilai minimal 75 ) dan hanya 2 orang $(3 \%)$ yang belum tuntas. Ini artinya batas ketuntasan klasikal (minimal $75 \%$ guru) telah tercapai. Meskipun begitu penelitian tetap dilanjutkan ke Siklus II untuk mencapai hasil yang lebih maksimal.

3. Dari 2 orang yang belum tuntas, diketahui belum membuat RPP dengan format yang sudah ditentukan. Dari pengakuannya, mereka kurang sungguh-sungguh dalam mengikuti supervisi secara online. Mereka berjanji pada siklus II akan sungguh-sungguh memperhatikan dan akan membuat RPP sesuai dengan format yang sudah ditentukan.

Pada siklus II seluruh guru (100\%) sudah membuat RPP dan semuanya telah mencapai batas minimal ketuntasan (nilai minimal 75). Termasuk 1 (satu) yang pada saat pra-siklus dan siklus I belum membuat, akhirnya dengan kesadarannya sendiri telah membuat dan tuntas.

Dengan demikian secara ringkas dapat digambarkan sebagai berikut. 
Tabel 1.

Prosentasi Ketuntasan Guru dalam Pembuatan RPP

\begin{tabular}{ccccc}
\hline \multirow{2}{*}{ NO } & \multirow{2}{*}{ SIKLUS } & \multirow{2}{*}{ TIDAK MEMBUAT } & \multicolumn{2}{c}{ MEMBUAT } \\
& & & TIDAK TUNTAS & TUNTAS \\
\hline 1 & Pra & $7(9 \%)$ & $48(62 \%)$ & $23(29 \%)$ \\
2 & 1 & $1(1 \%)$ & $2(3 \%)$ & $75(96 \%)$ \\
3 & II & 0 & 0 & $78(100 \%)$ \\
\hline
\end{tabular}

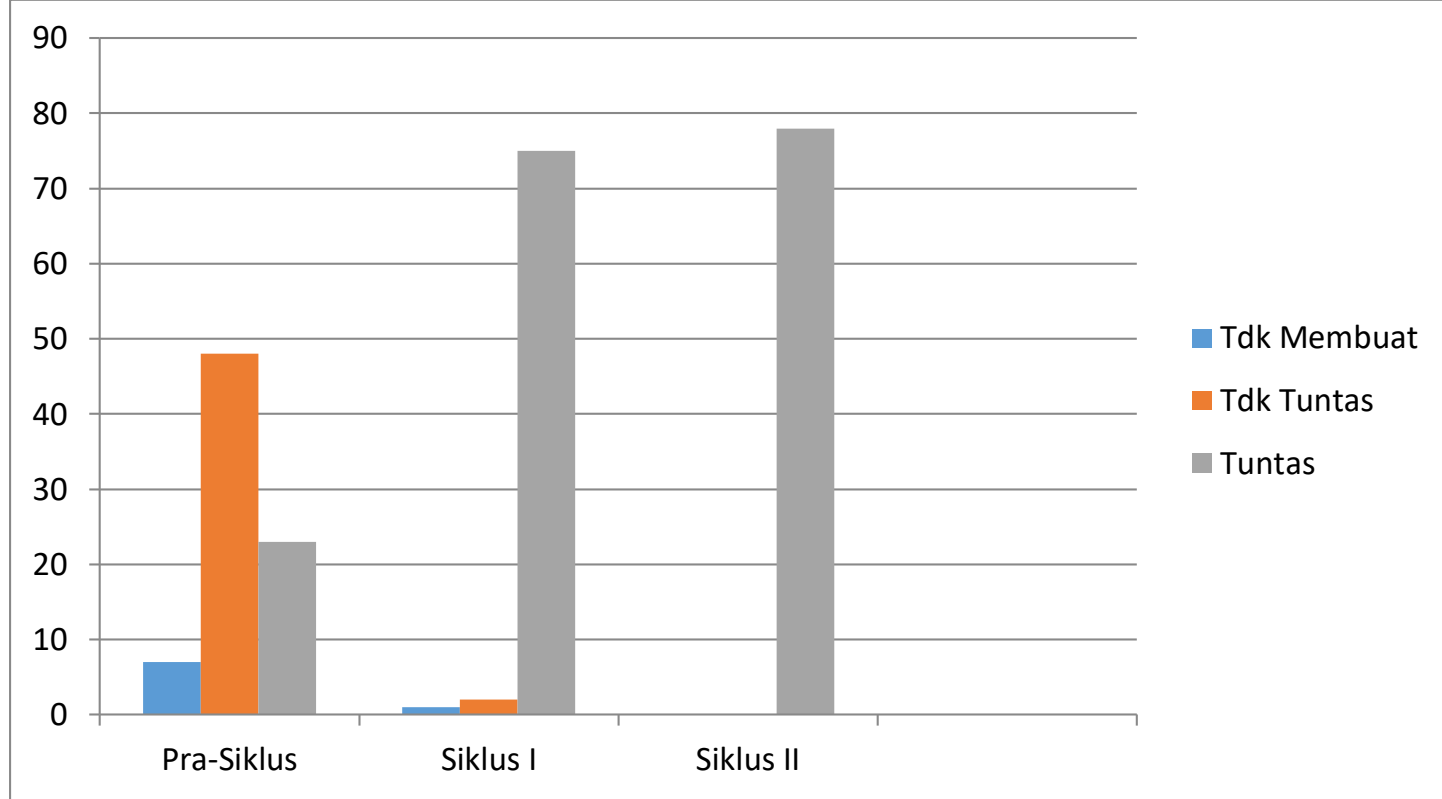

Gambar 1. Grafik Ketuntasan Guru

\section{KESIMPULAN}

Berdasarkan hasil Penelitian Tinadakan Sekolah (PTS) dapat disimpulkan sebagai berikut.

1. Supervisi kelompok dapat meningkatkan kompetensi guru dalam menyusun RPP. Nilai ratarata RPP pra-siklus 62, siklus I menjadi 93 dan siklus II naik menjadi 97. Ini berarti terjadi peningkatan $31 \%$ dari pra siklus ke siklus I. Pada siklus I nilai rata-rata RPP 93 dan pada siklus II naik menjadi 97 (naik $4 \%$ ). Hasil siklus II ini bila dibandingkan pra-siklus adalah naik dari nilai rata-rata 62 menjadi 97 . Ini berarti terjadi kenaikkan sebesar $35 \%$.

2. Supervisi kelompok akan dapat meningkatkan jumlah guru yang menyusun RPP. Pada prasiklus terdapat 7 guru (9\%) dari 78 yang tidak membuat RPP. Pada siklus I guru yang tidak membuat RPP 1 orang (3\%) dan pada siklus II seluruh guru (100\%) sudah membuah RPP sendiri.

Supervisi kelompok terbukti mampu meningkatkan kompetensi dan jumlah guru dalam menyusun RPP. Oleh karena itu, peneliti menyampaikan beberapa saran sebagai berikut.

1. Motivasi yang sudah tertanam khususnya dalam penyusunan RPP hendaknya terus dipertahankan dan ditingkatkan/ dikembangkan dalam praktik pembelajaran.

2. RPP yang disusun lengkap dan baik agar menjadi acuan/pedoman guru dalam melaksanakan pembelajaran.

3. Dokumen RPP hendaknya dibuat minimal dua rangkap, satu untuk arsip sekolah dan satunya lagi untuk pegangan guru dalam melaksanakan proses pembelajaran.

\section{REKOMENDASI}

Berdasarkan pelaksanaan dan hasil penelitian di atas, peneliti merekomendasikan :

1. Untuk penelitian berikutnya

a. Peneliti segera melakukan orientasi masalah apa yang harus segera diselesaikan yang dapat menjadi obyek penelitian tindakan sekolah; 
b. Peneliti mempersiapkan diri dengan pustaka yang lebih lengkap dan terkini untuk meningkatkan bobot kualitas penelitiannya;

c. Peneliti agar terus melaksanakan penelitian secara periodik untuk mendapatkan solusi terhadap permasalahan yang dihadapi sekolah dalam rangka meningkatkan layanan pendidikan yang lebih bermutu.

2. Untuk peneliti lainnya

a. Banyak masalah di sekolah yang dapat dijadikan sebagai bahan penelitian. Karena itu sebaiknya setiap kepala sekolah dapat melembagakan budaya ilmiah ini sebagai bagian dari budaya sekolah;

b. Kepala sekolah yang terbiasa melakukan penelitian tindakan sekolah bukan hanya terjadi peningkatan kualitas pendidikan di sekolahnya, tetapi juga mendorong dan memotivasi guru-guru untuk melakukan penelitian;

c. Kepada kepala sekolah yang belum terbiasa melakukan penelitian tindakan sekolah, segera saja mencoba. Mungkin hasil penelitian dapat dijadikan inspirasi.

\section{UCAPAN TERIMA KASIH}

Keberhasilan penelitian ini bukan semata-mata kemampuan peneliti sendiri tetapi banyak pihak telah berkontribusi. Untuk itu ucapan terima kasih yang setulus-tulusnya kami sampaikan kepada Wakil kepala sekolah bidang kurikulum, Ibu Nining Mariyaningsih, S.Pd., M.Pd. yang membantu penulis mendokumentasikan RPP yang dibuat para guru; Ibu Florens Nurhayati, S.Kom yang telah membantu penulis dalam mempersiapkan dan memfasilitasi sistem IT sehingga supervisi kelompok dapat berlangsung secara online; Seluruh Bapak dan Ibu Guru SMK Negeri 1 Salatiga yang sangat kooperatif dan penuh motivasi mengikuti supervisi kelompok penyusunan RPP dan Semua pihak yang telah membantu penulis dalam menyelesaikan penelitian baik secara langsung maupun tidak langsung yang tidak dapat disebutkan satu per satu.

\section{DAFTAR PUSTAKA}

Agung, S., Leo, \& Wahyuni, S. (2013). Perencanaan Pembelajaran Sejarah. Yogyakarta: Ombak.

Aqib, Z. (2007). Profesionalosme Guru Dalam Pembelajaran. Surabaya: Insan Cendekia.

Dewi, Kurniawati Eni . 2009. Pengembangan Bahan Ajar Bahasa Dan Sastra Indonesia Dengan Pendekatan Tematis. Tesis. Surakarta: Program Pascasarjana Universitas Sebelas Maret.

Depdiknas. 2003. UU RI No. 20 Tahun 2003 tentang Sistem Pendidikan Nasional. Jakarta: Depdiknas.

Diat, P., Lantip, \& Sudiyono. (2011). Supervisi Pendidikan. Yogyakarta: Gava Media.

Juni, P., Donni, \& Somad, R. (2014). Manajemen Supervisi dan Kepemimpinan Kepala Sekolah. Bandung: Alfabeta.

Majis, A. (2012). Perencanaan Pembelajaran. Bandung: Rosdakarya.

M. Ngalim Perwanto. (2012). Supervisi Pendidikan. Bandung: Rosdakarya.

Mukhtar, \& Iskandar. (2013). Orientasi Baru Supervisi Pendidikan. Jakarta: Referensi.

Mulyasa. (2011). Menjadi Kepala Sekolah Profesional. Bandung: Rosda.

Mulyasa, E. (2011). Menjadi Kepala Sekolah Profesional. Bandung: PT Remaja Rosdakarya. 
Nawawi, Hadari. 1985. Metode Penelitian Bidang Sosial. Yogyakarta: Gadjah Mada University Press.

Nurhadi. 2004. Kurikulum 2004. Jakarta: PT Gramedia Widiasarana Indonesia.

Sahertian, P. (2000). Konsep Dasar dan Tehnik Supervisi Pendidikan dalam rangka Pengembangan Sumber Daya Manusia. Jakarta: Rineka Cipta.

Sudarsono, FX. (1999). Pengantar Penelitian Tindakan Sekolah (PTS). Yogyakarta: Hikayat Publishing.

Suhardan, Dadang. (2010). Supervisi Profesional. Bandung: Alfabeta.

Suparlan. 2005. Menjadi Guru Efektif. Yogyakarta: Hikayat Publishing.

Sutisna, Oteng. (1983). Supervisi Pendidikan. Jakarta: PT Gramedia Widiasarana Indonesia. 2004. Standar Kompetensi Guru Sekolah Dasar. Jakarta: Depdiknas. 2005. UU RI No. 14 Tahun 2005 tentang Guru dan Dosen. Jakarta: Depdiknas. 2016. Permendikbud RI No. 22 Tahun 2016 tentang Standar Proses. Jakarta: Depdikbud.

2012. Teknik-Teknik Supervisi Pendidikan (http://rifaty.blogspot.com/2012/10/teknik-tekniksupervisi-pendidikan.html diakses 14 Juli 2018).

,2012. Teknik-Teknik Supervisi Kelompok. (http://kanguut.blogspot.com/2012/05/teknikteknik-supervisi-kelompok.html diakses 14 Juli 2018).

,Peraturan Pemerintah no 19 tahun 2005 tentang Standar Nasional Pendidikan . (2002). Kamus Besar Bahasa Indonesia. Jakarta: Balai Pustaka. 